\title{
Структура, оптические и фотоэлектрические свойства пленок сульфида свинца, легированных стронцием и барием
}

\author{
(C) Л.Н. Маскаева ${ }^{1,2}$, Е.В. Мостовщикова ${ }^{3}$, В.И. Воронин ${ }^{3}$, Е.Э. Лекомцева ${ }^{1}$, П.С. Богатова ${ }^{1}$, В.Ф. Марков ${ }^{1,2}$ \\ ${ }^{1}$ Уральский фредеральный университет им. первого Президента России Б.Н. Ельцина, \\ 620002 Екатеринбург, Россия \\ 2 Уральский институт государственной противопожарной службы МЧС России, \\ 620062 Екатеринбург, Россия \\ ${ }^{3}$ Институт фризики металлов им. М.Н. Михеева Уральского отделения Российской академии наук, \\ 620108 Екатеринбург, Россия \\ E-mail: mln@ural. ru
}

Поступила в Редакцию 25 мая 2020 г.

В окончательной редакции 8 июня 2020 г.

Принята к публикации 8 июня 2020 г.

\begin{abstract}
Изучена эволюция морфологии, состава, структурных характеристик (постоянной решетки, микродеформаций, текстурированности), оптических и фотоэлектрических свойств пленок $\mathrm{PbS}$, полученных гидрохимическим осаждением в присутствии иодида аммония и хлоридов стронция или бария при концентрации до 5 ммоль/л. По данным элементного EDX-анализа, содержание стронция в пленках $\mathrm{PbS}$ составляет 0.4-0.7 ат\%, а барий находится за пределом ошибки определения. Размер частиц, формирующих пленки, варьируется от $\sim 200$ до $\sim 400 \mathrm{Hм}$, а распределение частиц по размерам является мономодальным. Введение в реактор $\mathrm{NH}_{4} \mathrm{I}$ и $\mathrm{SrCl}_{2}$ или $\mathrm{BaCl}_{2}$ сохраняет кубическую $B 1$ структуру сульфида свинца, но приводит к немонотонному изменению параметра решетки, что связано с созданием дефектов типа вакансии или ионов внедрения. Введение солей стронция и бария не влияет на ширину запрещенной зоны, однако приводит к изменению интенсивностей примесных полос поглощения в глубине запрещенной зоны и вблизи дна зоны проводимости. Зависимость вольт-ваттной чувствительности пленок от концентрации солей стронция и бария в растворе носит экстремальный характер с максимумами при 0.05 и 0.1 ммоль./л соответственно.
\end{abstract}

Ключевые слова: сульфид свинца, тонкие пленки, кристаллическая структура, стронций, барий, оптические свойства, фоточувствительность.

DOI: $10.21883 /$ FTP.2020.10.49941.9448

\section{1. Введение}

Тонкопленочный сульфид свинца $\mathrm{PbS}$ занимает одно из важнейших мест в ряду узкозонных полупроводников $\left(E_{g}=0.41\right.$ эВ при $\left.300 \mathrm{~K}[1]\right)$, используемых для создания детекторов ИК-излучения $[1,2]$, используемых в области 0.4-3.2 мкм. Разнообразие и специфичность свойств этого соединения обусловливает его широкое применение для изготовления полупроводниковых лазеров среднего инфракрасного диапазона [2], химических сенсоров [3,4], датчиков пожара [5], преобразователей солнечного излучения [6], создания квантовых точек [7].

Широко используемым способом получения сульфида свинца в тонкопленочном состоянии является химическое осаждение из водных растворов [8-17]. Метод отличается технологической простотой и возможностью контролируемого варьирования электрофизических и фотоэлектрических свойств осаждаемых пленок за счет изменения условий их синтеза и состава реакционной смеси. Требуемую комбинацию оптических и электрофизических свойств сульфида свинца можно задавать, целенаправленно изменяя морфологию, состав и структурные характеристики осаждаемых слоев.

Эффективным приемом синтеза пленок $\mathrm{PbS}$ с требуемыми свойствами является введение в реакционную смесь различных легирующих добавок, активно влияющих как на протекание процесса осаждения пленок, так и на формирование их полупроводниковых и фотоэлектрических свойств. Например, введение галогенид-ионов $\left(\mathrm{Cl}^{-}, \mathrm{Br}^{-}, \mathrm{I}^{-}\right)$, выступающих в роли доноров [8], или ионов металлов первой группы $\left(\mathrm{Li}^{+}, \mathrm{Na}^{+}, \mathrm{K}^{+}\right)$[9], являющихся акцепторной примесью [10], оказывает выраженное влияние на микроструктуру, тип проводимости и величину фотоответа осажденных слоев.

Влияние солей щелочноземельных металлов, используемых в качестве допантов, на структурные характеристики и свойства пленок $\mathrm{PbS}$ до настоящего времени изучено относительно слабо. Из работ последнего десятилетия следует отметить публикации по легированию при химическом осаждении сульфида свинца магнием [11-13], кальцием [14,15] и стронцием [16]. В них анализируется влияние легирующих добавок на морфологию, параметры кристаллической решетки пленок и их оптические свойства. Как отмечается авторами этих работ, введение допантов в реактор приводит к уменьшению размеров кристаллитов, формирующих пленку $\mathrm{PbS}$, однако не всегда однозначно влияет на величину запрещенной зоны. Так, в случае использования в качестве допанта магния наблюдалось уменьшение размера частиц с $\sim 89$ до 72 нм [12], при введении соли кальция 
размер снижался до 11 нм [15], а добавка соли стронция уменьшала средний размер кристаллитов до 9нм [16]. При этом в [12] показано увеличение ширины запрещенной зоны гидрохимически осажденных пленок $\mathrm{PbS}$ до 1.1 эВ, а в [16] по результатам анализа спектров поглощения величина запрещенной зоны пленок $\mathrm{PbS}$ при увеличении концентрации допанта до 5 мас\% возрастала до 2.19эВ. В этой работе проанализировано также изменение микронапряжений, плотности дислокаций и плотности межкристаллитных зазоров в пленках в зависимости от содержания в растворе соли стронция. Увеличение величины оптической ширины запрещенной зоны $\mathrm{PbS}$, как правило, связывалось с влиянием размерного эффекта, поскольку размер кристаллитов в приведенных работах $[14,15]$ был меньше, чем характерный размер экситона Ванье-Мотта или незначительно превышал его.

Важно отметить, что при анализе оптических свойств анализировались спектры поглощения только в видимой области спектра, а оценка ширины запрещенной зоны проводилась экстраполяцией экспериментальных данных из области высоких энергий, что отражалось на точности результата. В отличие от обсуждаемых выше работ, нами в [17] были исследованы пленки, легированные кальцием, в которых отсутствовал размерный эффект, поскольку размер кристаллитов составлял 150-200 нм. Было показано, что ширина запрещенной зоны легированных Са слоев даже несколько снижалась по сравнению с индивидуальным сульфидом свинца, составляя $\sim 0.40$ эВ при комнатной температуре и 0.38 эВ при $T=90 \mathrm{~K}$.

Отметим, что анализ научной литературы выявил неоднозначность имеющихся сведений о легирующем действии щелочноземельных металлов на структурные характеристики пленок $\mathrm{PbS}$ и его полупроводниковые свойства. Требует также дальнейшего изучения вопрос о влиянии микроструктуры подобных слоев на величину $E_{g}$ сульфида свинца.

Из работ $[18,19]$, в которых упоминается легирование пленок барием, можно отметить следующее. В первой из них пленки $\mathrm{PbS}$ были получены методом SILAR. Показано, что с увеличением концентрации бария в слое повышаются коэффициент пропускания и оптическая ширина запрещенной зоны сульфида свинца [18]. В [19] приведены результаты изучения кинетики процесса осаждения и морфологические особенности полученных пленок PbS. Однако структурных и оптических исследований пленок сульфида свинца, осажденных в присутствии солей бария, до настоящего времени не проводилось.

Добавим, что в известных нам работах по изучению влияния щелочноземельных элементов на свойства пленок $\mathrm{PbS}$, за исключением работы [17], в которой рассматривалось легирование кальцием, отсутствуют сведения о фотоэлектрических свойствах. Информация о них, несомненно, очень важна с точки зрения практического применения пленок сульфида свинца.
C учетом изложенного цель настоящей работы заключалась в исследовании кристаллической структуры, состава, оптических и фотоэлектрических свойств пленок $\mathrm{PbS}$, гидрохимически осажденных с добавлением солей стронция и бария. Результаты этих исследований, полученные в сопоставимых условиях, позволят провести сравнительную оценку и выявить общие тенденции изменения свойств пленок сульфида свинца, синтезированных в присутствии щелочноземельных металлов.

\section{2. Методика эксперимента}

Пленки сульфида свинца получали гидрохимическим осаждением по ранее предложенной методике [17] из реакционной смеси, содержащей фиксированные концентрации тиомочевины $\left(\mathrm{NH}_{2}\right)_{2} \mathrm{CS}$, выступающей в роли халькогенизатора, ацетата свинца $\mathrm{Pb}\left(\mathrm{CH}_{3} \mathrm{COO}\right)_{2}$, цитрата натрия $\mathrm{Na}_{3} \mathrm{C}_{6} \mathrm{H}_{5} \mathrm{O}_{7}$, водного раствора аммиака $\mathrm{NH}_{4} \mathrm{OH}$ и иодида аммония $\mathrm{NH}_{4} \mathrm{I}$. Легирование пленок щелочноземельными металлами в процессе химического осаждения осуществляли путем дополнительного введения в реактор от 0.05 до 5.0 ммоль/л хлоридов стронция или бария. Для оценки эффективности легирующих добавок в работе исследовали пленки нелегированного сульфида свинца $\mathrm{PbS}$, с добавками только иодида аммония $\mathrm{PbS}(\mathrm{I})$, иодида аммония и солей стронция $\mathrm{PbS}(\mathrm{I}, \mathrm{Sr})$ или бария $\mathrm{PbS}(\mathrm{I}, \mathrm{Ba})$. Пленки осаждали на предварительно подготовленные подложки из ситалла и стекла. Синтез пленок осуществляли в течение 90 мин при $353 \mathrm{~K}$ в жидкостном термостате „ТС-ТБ-10“, обеспечивающем точность поддержания температуры $\pm 0.1 \mathrm{~K}$.

Толщину полученных пленок оценивали с помощью интерференционного микроскопа (микроинтерферометра Линника) МИИ-4М с погрешностью измерения, равной $10 \%$.

Методом растровой электронной микроскопии с использованием микроскопа MIRA 3 LMU при ускоряющем напряжении электронного пучка 15 кВ и растрового электронного микроскопа JEOL JSM-5900 LV с приставкой для энергодисперсионного анализа EDS Inca Energy 250 исследовали структурно-морфологические характеристики и элементный состав пленок $\mathrm{PbS}$ с погрешностью определения $\sim 10 \%$.

Сравнительные исследования кристаллической структуры пленок сульфида свинца проводили методом рентгеновской дифракции на дифрактометре ДРОН-4. Рентгенограммы снимали в $\mathrm{Cu} K_{\alpha 1,2}$-излучении в интервале углов $2 \theta$ от 20 до $80^{\circ}$ в режиме пошагового сканирования с $\Delta(2 \theta)=0.03^{\circ}$ и временем накопления сигнала в точке 5-10 с. Анализ экспериментальных спектров был выполнен методом полнопрофильного анализа Ритвелда [20] с использованием программного пакета FullProf [21]. Для моделирования профиля рефлексов использовали функцию псевдо-Фойгта. Для описания 
Параметр решетки $(a)$, доля зерен с преимущественной ориентацией (111) или (200) перпендикулярно плоскости подложки $\left(\mathrm{T}_{111}, \mathrm{~T}_{200}\right)$, среднее значение микродеформации $(\Delta d / d)$, размер областей когерентного рассеяния ОКР $(D)$ и элементный состав пленок $\mathrm{PbS}, \mathrm{PbS}(\mathrm{I}), \mathrm{PbS}(\mathrm{I}, \mathrm{Sr}), \mathrm{PbS}(\mathrm{I}, \mathrm{Ba})$

\begin{tabular}{|c|c|c|c|c|c|c|}
\hline \multirow{2}{*}{ Параметр } & \multirow{2}{*}{$\mathrm{PbS}$} & \multirow{2}{*}{$\operatorname{PbS}(\mathrm{I})$} & \multicolumn{2}{|c|}{$\mathrm{PbS}(\mathrm{I}, \mathrm{Sr})$} & \multicolumn{2}{|c|}{$\mathrm{PbS}(\mathrm{I}, \mathrm{Ba})$} \\
\hline & & & 0.05 ммоль/л & 5 ммоль/л & 0.05 ммоль/л & 5 ммоль/л \\
\hline$a, \mathrm{HM}$ & $0.59326(2)$ & $0.59343(2)$ & $0.59345(1)$ & $0.59328(2)$ & $0.59313(2)$ & $0.59327(1)$ \\
\hline $\mathrm{T}_{111}, \%$ & $33.4 \pm 0.4$ & - & - & - & - & - \\
\hline $\mathrm{T}_{200}, \%$ & - & $21.5 \pm 0.8$ & $15.2 \pm 0.8$ & $34.2 \pm 0.3$ & $11.5 \pm 0.8$ & $18.5 \pm 0.6$ \\
\hline$D, \mathrm{HM}$ & $66 \pm 10$ & $220 \pm 20$ & $240 \pm 30$ & $380 \pm 50$ & $240 \pm 30$ & $285 \pm 50$ \\
\hline$\Delta d / d \cdot 10^{-4}$ & $14 \pm 1$ & $27 \pm 5$ & $21 \pm 1$ & $23 \pm 5$ & $17 \pm 5$ & $19 \pm 5$ \\
\hline $\mathrm{Pb}, \mathrm{aT} \%$ & 50.1 & 49.8 & 49.7 & 49.9 & 49.8 & 49.9 \\
\hline $\mathrm{S}, \mathrm{aT} \%$ & 49.9 & 48.8 & 49.0 & 48.9 & 49.4 & 49.7 \\
\hline $\mathrm{I}, \mathrm{aT} \%$ & - & 1.4 & 1.1 & 1.0 & 0.8 & 0.4 \\
\hline $\mathrm{Sr}(\mathrm{Ba}), \mathrm{aT}^{\%} \%$ & - & - & $\begin{array}{c}0.4-0.7 \\
\text { (в глобулах) }\end{array}$ & $\begin{array}{c}0.4-0.7 \\
\text { (в глобулах) }\end{array}$ & - & - \\
\hline
\end{tabular}

анизотропии уширения дифракционных пиков применяли процедуры анализа, содержащиеся в программе Fullprof [21], с использованием эталонной функции разрешения прибора. Функция разрешения рентгеновского дифрактометра Дрон-4 была получена при съемке эталонных порошковых образцов $\mathrm{Na}_{2} \mathrm{Al}_{2} \mathrm{Ca}_{3} \mathrm{~F}_{12}$ и $\mathrm{CeO}_{2}$.

Оптические исследования пленок, осажденных на стеклянной подложке, проводили в ближнем ИК диапазоне в интервале $0.2<E<1.1$ эВ при 300 и $90 \mathrm{~K}$ с использованием призменного спектрометра. Спектры поглощения $\alpha(E)$ рассчитывали из экспериментально полученных спектров пропускания $t(E)$ без учета отражения по формуле

$$
\alpha(E)=\frac{1}{d_{f}} \ln \left(\frac{1}{t(E)}\right),
$$

где $d_{f}$ - толщина пленки, $t(E)=I / I_{0}-$ пропускание пленки, $I, I_{0}$ - интенсивность света, прошедшего через пленку и через подложку соответственно.

Фотоэлектрические характеристики пленок (темнового сопротивления, вольт-ваттной чувствительности) измеряли на установке К.54.410 с источником излучения АЧТ $573 \mathrm{~K}$ при частоте модуляции излучения 800 Гц и облученности $1 \cdot 10^{-4} \mathrm{BT} / \mathrm{cm}^{2}$.

\section{3. Результаты и их обсуждение}

\section{1. Морфология и элементный состав}

Гидрохимическим осаждением получены пленки, толщина которых варьировалась в зависимости от природы и содержания легирующих добавок в реакционной ванне. Так, нелегированная пленка $\mathrm{PbS}$ имела толщину $\sim 400$ нм, добавка иодида аммония приводила к уменьшению толщины пленки $\mathrm{PbS}(\mathrm{I})$ до 350 нм. В результате совместного введения иодида аммония и хлорида стронция или бария в реактор толщина пленок, осаждаемых в течение того же времени, уменьшалась. Тонкопленочные слои, полученные в присутствии 0.05 ммоль/л хлорида стронция или бария, имели толщину $\sim 270 \mathrm{HM}$, а в присутствии 5.0 ммоль/л соответствующей соли допанта толщина составляла $\sim 150$ нм для $\mathrm{PbS}(\mathrm{I}, \mathrm{Sr})$ и $\sim 220 \mathrm{Hм}$ для $\mathrm{PbS}(\mathrm{I}, \mathrm{Ba})$.

Электронно-микроскопические изображения обсуждаемых слоев $\mathrm{PbS}, \mathrm{PbS}(\mathrm{I}), \mathrm{PbS}(\mathrm{I}, \mathrm{Sr}), \mathrm{PbS}(\mathrm{I}, \mathrm{Ba})$ приведены на рис. 1. Видно, что пленка нелегированного сульфида свинца состоит из хорошо ограненных кристаллитов со средними размерами в плоскости подложки $\sim 200-300$ нм (рис. 1, $a$ ). Введение иодида аммония приводит к нарушению кристаллической огранки пленки $\mathrm{PbS}(\mathrm{I})$ : на фоне достаточно однородной микроструктуры наблюдаются единичные глобулы размером до 1 мкм (рис. $1, b)$. Введение в реакционную смесь хлоридов стронция или бария до 5.0 ммоль/л в присутствии иодида аммония существенно не влияет на средний размер кристаллитов, формирующих пленки, и на распределение частиц по размерам.

Как видно из приведенных гистограмм, характер распределения формирующих пленки частиц по размерам во всех изученных слоях является фактически мономодальным (рис. 1). В синтезированных пленках $\mathrm{PbS}, \mathrm{PbS}(\mathrm{I}), \operatorname{PbS}(\mathrm{I}, \mathrm{Sr})$ и $\mathrm{PbS}(\mathrm{I}, \mathrm{Ba})$ преобладающими являются размеры зерен 200-300, 150-250, 150-300, $150-250$ нм при их процентном содержании в слое $\sim 37$, $\sim 72, \sim 79, \sim 70 \%$ соответственно. Доля нанодисперсий в структуре обсуждаемых пленок относительно невелика и составляет от 1 до $4 \%$.

Проведенный локальный элементный анализ показал, что в нелегированной пленке $\mathrm{PbS}$ наблюдается незначительное отклонение от стехиометрии при содержании 50.1 ат\% свинца и 49.9 ат\% серы (см. таблицу). В пленке $\mathrm{PbS}(\mathrm{I})$, осажденной в присутствии иодида аммония, избыток ионов свинца сохраняется при соотношении между основными элементами (Pb:S как 49.8 и $48.8 \mathrm{aT} \%)$ с содержанием иода, не превышающим $1.4 \mathrm{aT} \%$. 
$a$
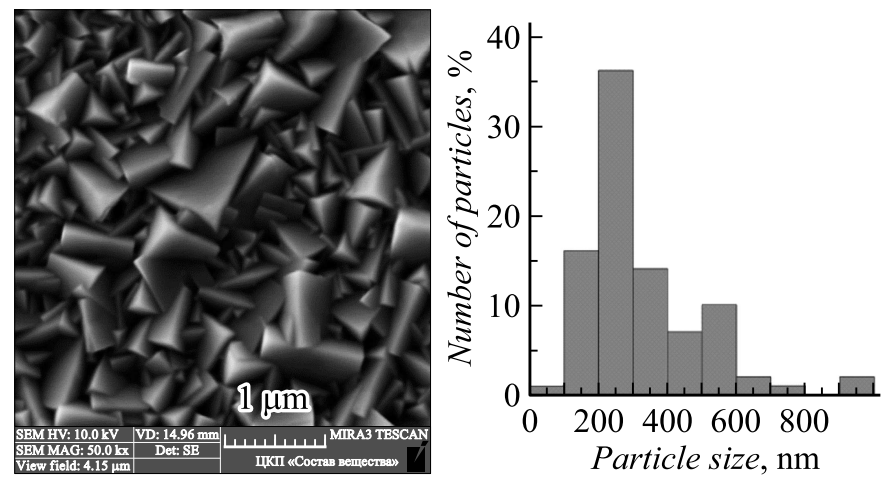

$c$
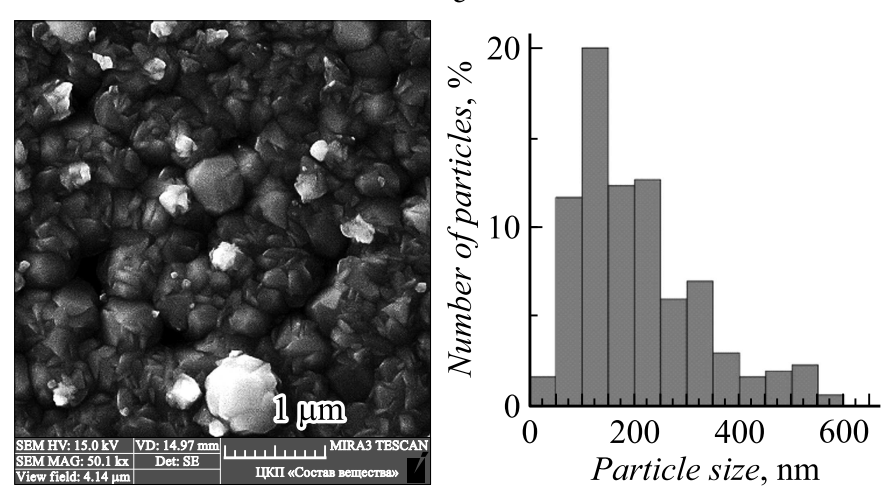

$e$

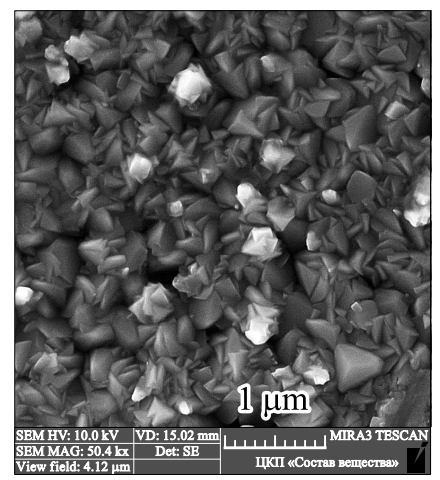

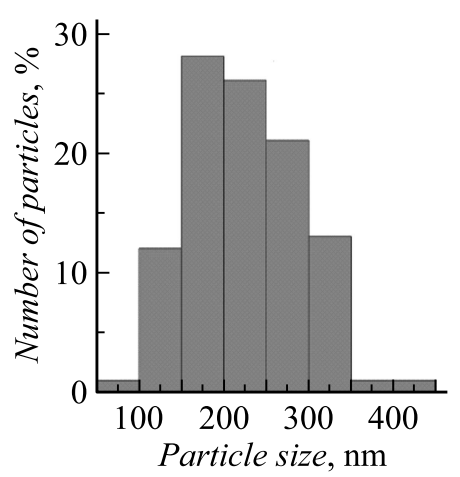

$b$
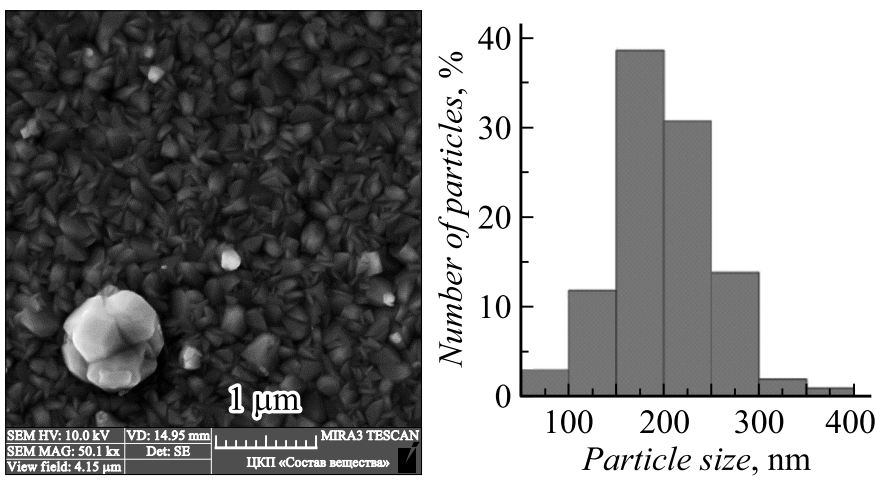

$d$
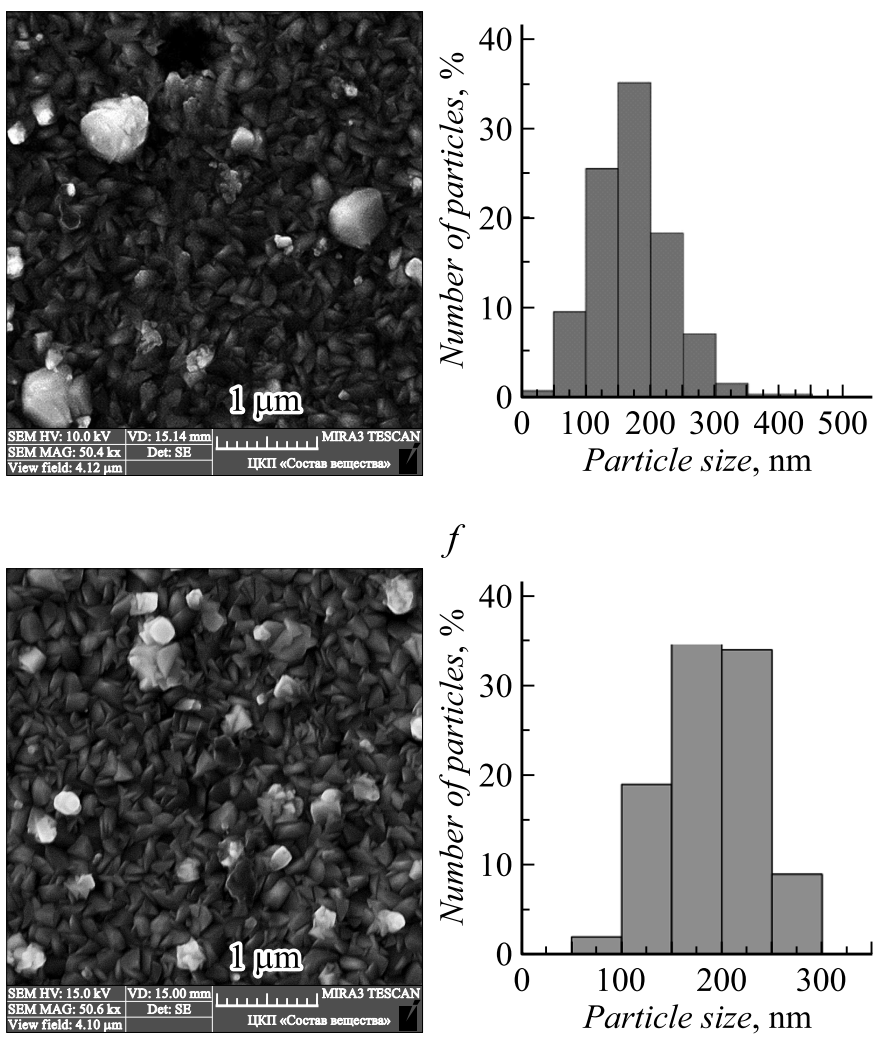

$f$

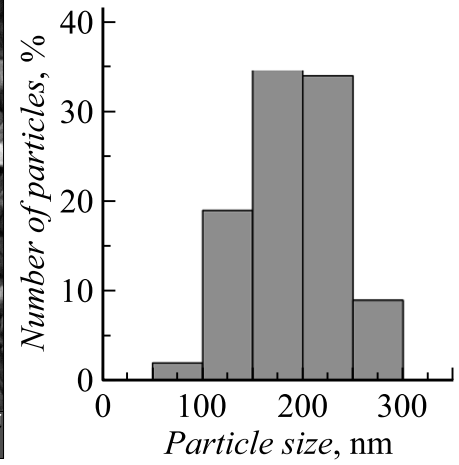

Рис. 1. Электронно-микроскопические изображения пленок $\mathrm{PbS}(a), \operatorname{PbS}(\mathrm{I})(b), \operatorname{PbS}(\mathrm{I}, \mathrm{Sr})(c, d), \operatorname{PbS}(\mathrm{I}, \mathrm{Ba})(e, f)$ и гистограммы распределения в них частиц по размерам. Пленки $(c, e)$ и $(d, f)$ получены соответственно при содержании 0.05 и 5.0 ммоль/л солей $\mathrm{SrCl}_{2}$ и $\mathrm{BaCl}_{2}$ в реакторе.

EDX-анализом в пленках, синтезированных в присутствии соли $\mathrm{SrCl}_{2}$, легирующий элемент обнаруживается только в глобульных образованиях, и его концентрация составляет от 0.4 до 0.7 ат\%. В обсуждаемых слоях состав основных элементов - свинца (49.9 ат\%) и серы $(49.0$ ат\%) практически идентичен составу пленки $\mathrm{PbS}(\mathrm{I})$. Однако происходит снижение в них иода до $1.1 \mathrm{aT} \%$. Можно предположить, что вхождение ионов стронция в пленку аналогично поведению кальция при легировании им сульфида свинца [17] и имеет точечный характер с образованием дефектов типа пар Френкеля (вакансия + межузельный атом) [22].
По результатам локального анализа в пленках сульфида свинца, полученных в присутствии $\mathrm{BaCl}_{2}$, при всех используемых в работе концентрациях этой соли (0.05-5 ммоль/л) барий обнаружить не удалось. Возможными причинами отсутствия следов этого элемента в EDX-спектрах могут быть либо низкая чувствительность используемого метода, либо затруднения, связанные с вхождением в кристаллическую решетку $\mathrm{PbS}$ относительно больших по размерам ионов $\mathrm{Ba}^{2+}(0.135 \mathrm{Hм})$ по сравнению с ионами свинца $\mathrm{Pb}^{2+}(0.119$ нм $)$ [23].

Анализируя полученные результаты, а также данные работы [17], можно выделить характерную тенденцию 
снижения содержания в пленках сульфида свинца щелочноземельных металлов-допантов от кальция к барию при введении их солей в реакционную смесь. В приведенном ряду содержание этих элементов постепенно уменьшается от 1.13 и $0.4-0.7 \mathrm{aT} \%$ соответственно для кальция и стронция до фактического отсутствия бария. Отметим, что полученный ряд допантов коррелирует с увеличением ионных радиусов этих элементов [23]: $0.100,0.118$ и 0.135 нм для $\mathrm{Ca}^{2+}, \mathrm{Sr}^{2+}$ и $\mathrm{Ba}^{2+}$ соответственно.

\section{2. Кристаллическая структура}

На рентгенограммах синтезированных пленок $\mathrm{PbS}$, $\mathrm{PbS}(\mathrm{I}), \operatorname{PbS}(\mathrm{I}, \mathrm{Sr})$ и $\mathrm{PbS}(\mathrm{I}, \mathrm{Ba})$ присутствует набор дифракционных отражений (111), (200), (220) и (311), характерных кубическому (пр. гр. $F m \overline{3} m$ ) сульфиду свинца со структурой $B 1$ (рис. 2). Изменение соотношения интенсивностей дифракционных отражений, соответствующих плоскостям $(111)_{B 1}$ и $(200)_{B 1}$, в рентгенограммах пленок $\mathrm{PbS}$ после легирования иодом, а затем стронцием или барием обусловлено трансформацией преимущественной кристаллографической ориентации зерен в изученных тонкопленочных слоях при легировании. В пленке $\mathrm{PbS}$ кристаллиты расположены плоскостью $(111)_{B 1}$ перпендикулярно поверхности подожки, а в пленках $\mathrm{PbS}(\mathrm{I}), \mathrm{PbS}(\mathrm{I}, \mathrm{Sr})$ и $\mathrm{PbS}(\mathrm{I}, \mathrm{Ba})$ - плоскостью $(200)_{B 1}$. Это наглядно видно на микроизображениях этих пленок (рис. 1), а также по коэффициенту их текстурированности, оцененному из соотношения интенсивностей дифракционных пиков (см. таблицу).

Для понимания эволюции структурных свойств пленок $\mathrm{PbS}(\mathrm{I}, \mathrm{Sr})$ и $\mathrm{PbS}(\mathrm{I}, \mathrm{Ba})$, осажденных в присутствии солей стронция и бария, сравним вначале влияние добавки иода на структурные свойства нелегированной пленки сульфида свинца. Введение в реакционную ванну иодида аммония приводит к формированию пленки $\mathrm{PbS}(\mathrm{I})$, дифракционные отражения которой смещены относительно рефлексов нелегированного слоя $\mathrm{PbS}$, что связано с увеличением периода решетки кубического сульфида свинца $a_{B 1}$ от $0.59326(2)$ до $0.59343(2)$ нм (см. таблицу). Этот факт был интерпретирован нами как замещение имеющих меньший радиус ионов серы $\mathrm{S}^{2-}(0.182 \mathrm{Hм})$ более крупными иодид-ионами $\mathrm{I}^{-}(0.220 \mathrm{Hм})[23]$ в кристаллической решетке $\mathrm{PbS}$, либо внедрением в нее до 1.4 ат\% иода (см. таблицу). Аналогичный эффект вхождения иода в кристаллическую решетку установлен при легировании этим же галогеном тонкопленочного слоя $\mathrm{PbSe}$ [24].

Дополнительное введение хлорида стронция в реактор приводит к следующим изменениям в пленке сульфида свинца. Вначале при концентрации 0.05 ммоль/л $\mathrm{SrCl}_{2}$ в реакционной смеси происходит незначительное увеличение периода кристаллической решетки $\mathrm{PbS}(\mathrm{I}, \mathrm{Sr})$ до $0.59345(1)$ нм по сравнению с параметром $a_{B 1}$ пленки $\mathrm{PbS}(\mathrm{I})$. Это может быть обусловлено тем, что незначительная часть ионов $\mathrm{Sr}^{2+}(0.118 \mathrm{Hм})$ внедряется в кри-

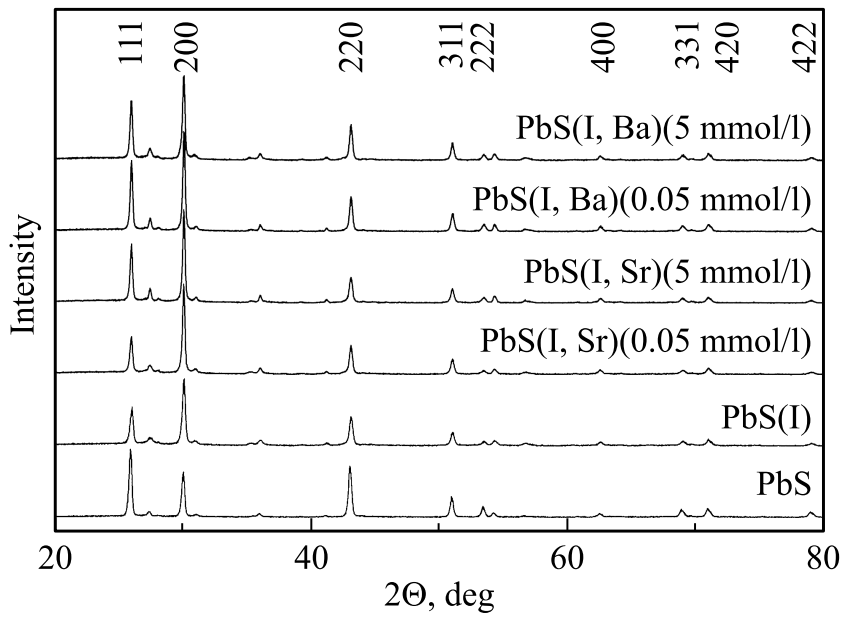

Рис. 2. Экспериментальные рентгенограммы пленок $\mathrm{PbS}$, $\mathrm{PbS}(\mathrm{I}), \operatorname{PbS}(\mathrm{I}, \mathrm{Sr})$ и $\mathrm{PbS}(\mathrm{I}, \mathrm{Ba})$, полученных при различных добавках солей стронция и бария. Излучение $\mathrm{Cu} K_{\alpha 1,2}$.

сталлическую решетку PbS. При повышении концентрации хлорида стронция до 5 ммоль/л, вероятно, создаются условия для замещения небольшого количества более крупных ионов свинца $\mathrm{Pb}^{2+}(0.119 \mathrm{нм})$ ионами $\mathrm{Sr}^{2+}$, что приводит к уменьшению периода кристаллической решетки до 0.59328(2) нм.

Как уже отмечалось, EDX-анализом барий не обнаружен в пленках сульфида свинца, синтезированных из реакционных ванн, содержащих от 0.05 до 5.0 ммоль/л хлорида бария. Тем не менее введение соли бария в реакционную ванну оказывает влияние на период кристаллической решетки получаемой пленки сульфида свинца: при минимальной концентрации соли бария в реакторе образуется пленка $\mathrm{PbS}(\mathrm{I}, \mathrm{Ba})$ с $a=0.59313(2) \mathrm{HM}$, что существенно меньше, чем постоянная элементарной ячейки пленки $\mathrm{PbS}(\mathrm{I})$. Основной причиной этих изменений может быть снижение содержания иода от 1.4 до $0.8 \mathrm{aT} \%$ в пленке $\mathrm{PbS}(\mathrm{I}, \mathrm{Ba})$. Стоит отметить, что в присутствии даже незначительного количества примесей в процессе кристаллизации может происходить формирование структуры с искаженной кристаллической решеткой, а также возникновение в ней точечных дефектов в виде вакансий по основным элементам [22]. $\mathrm{B}$ реакторе с максимальной концентрацией $\mathrm{BaCl}_{2}$ ионы бария блокируют интенсивный рост микрокристаллитов сульфида свинца, поэтому пленка формируется из более мелких частиц, плотно прилегающих друг к другу. При этом параметр кристаллической решетки увеличивается до 0.59327(1) нм, несмотря на снижение концентрации иода в пленке до 0.4 ат\%.

Уточнение структурных параметров пленок $\mathrm{PbS}$, $\mathrm{PbS}(\mathrm{I}), \operatorname{PbS}(\mathrm{I}, \mathrm{Sr})$ и $\mathrm{PbS}(\mathrm{I}, \mathrm{Ba})$ из экспериментальных рентгенограмм проведено методом полнопрофильного анализа Ритвелда с использованием программы Fullprof. Дифракционные отражения на рентгенограммах обсуждаемых пленок (рис. 2) уширены из-за относительно 

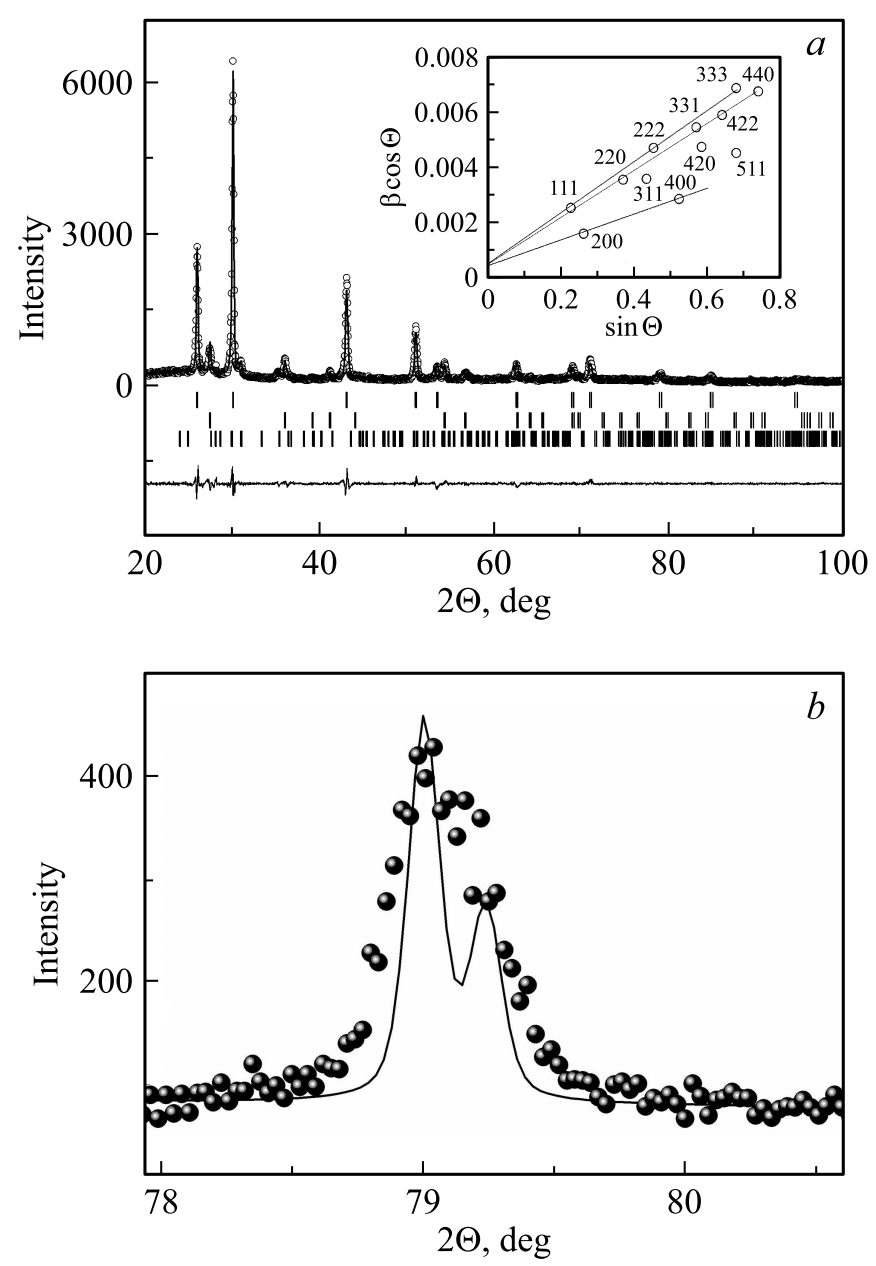

Рис. 3. Экспериментальная (кружки) и расчетная (сплошная линия) рентгенограммы синтезированной пленки $\mathrm{PbS}(\mathrm{I})$ c кубической (пр.гр. $F m \overline{3} m$ ) структурой типа $B 1$. В нижней части рисунка приведена разность между экспериментальной и расчетной рентгенограммами. Штрихи - угловые положения рефлексов $\mathrm{PbS}$ (верхние), от ситалловой подложки, содержащей $\mathrm{TiO}_{2}$ и кордиерит (средние и нижние) $(a)$. Экспериментальный (кружки) и эталонный (сплошная линия) рефлекс

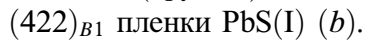

малого размера частиц и наличия микродеформаций. Разделение размерного и деформационного вкладов в уширение отражений и оценка среднего размера областей когерентного рассеяния (ОКР), принимаемого в первом приближении как средний размер зерен $(D)$, выполнено экстраполяционным методом УильямсонаХолла.

Как пример минимизации на рис. 3, $a$ показаны экспериментальная (кружки) и расчетная (сплошная линия) рентгенограммы синтезированной пленки $\mathrm{PbS}(\mathrm{I})$ с кубической (пр. гр. $F m \overline{3} m$ ) структурой типа $B 1$. На рисунке приведены дифракционные отражения от пленки (верхние), фаз $\mathrm{TiO}_{2}$ и кордиерита, принадлежащих ситалловой подложке (средние и нижние). Разность между экспериментальной и расчетной рентгенограммами подтвержда- ет высокую точность выполненного полнопрофильного анализа. На вставке рис. 3, a приведена зависимость $\beta \cos \theta$ от $\sin \theta$, позволяющая рассчитать микродеформации. На рис. $3, b$ показано уширение экспериментального рефлекса $(422)_{в 1}$ для пленки $\mathrm{PbS}(\mathrm{I})$ по сравнению с эталонным образцом.

Из экспериментальной зависимости $\beta \cos \theta=f(\sin \theta)$ для пленки $\mathrm{PbS}(\mathrm{I})$ можно сделать вывод о том, что средние значения величины $\beta \cos \theta$ близки $\theta$ при $\sin \theta$, стремящемся к нулю (см. вставку к рис. 3, $a$ ). Это говорит о том, что уширение дифракционных отражений главным образом связано с возникновением микронапряжений $\Delta d / d$ в обсуждаемой пленке. Нерегулярность в расположении точек на рисунке указывает на наличие анизотропии микронапряжений вдоль различных кристаллографических направлений. Действительно, соединив прямой линией точки для пространственных кристаллографических направлений $[h h h]$ и $[h 00]$, можно увидеть, что угол наклона отличается, указывая на различную величину микронапряжений вдоль этих направлений.

Аналогичная обработка рентгенограмм была проведена для всех синтезированных пленок $\mathrm{PbS}, \mathrm{PbS}(\mathrm{I}, \mathrm{Sr})$ и $\mathrm{PbS}(\mathrm{I}, \mathrm{Ba})$, что позволило констатировать существование в них анизотропии напряжений (см. таблицу). Результаты оценки микронапряжений свидетельствуют о почти двухкратном увеличении $\Delta d / d$ в пленках $\mathrm{PbS}(\mathrm{I})$ по сравнению с нелегированным слоем $\mathrm{PbS}$ за счет вхождения в кристаллическую структуру иодид-ионов (1.4 ат\%). В пленках $\mathrm{PbS}(\mathrm{I}, \mathrm{Sr})$ наблюдается снижение микродеформаций по сравнению с $\mathrm{PbS}(\mathrm{I})$ в 1.2-1.3 раза, что может быть связано с несколькими причинами. Во-первых, в пленках $\mathrm{PbS}(\mathrm{I}, \mathrm{Sr})$ снижено до 1.1 ат\% содержание иодид-ионов, а во-вторых, не исключено внедрение малоразмерных по сравнению со свинцом ионов $\mathrm{Sr}^{2+}$ в междоузлия кристаллической решетки $\mathrm{PbS}$ (при добавке 0.05 ммоль/л), либо замещение ионов свинца на стронций (при добавке 5 ммоль/л). Более значительное снижение микродеформаций в пленке $\mathrm{PbS}(\mathrm{I}, \mathrm{Ba})$ также связано с уменьшением содержания в них иода в 1.7 (0.05 ммоль/л) и 3.5 раза (5 ммоль/л). Авторы работы [25] полагают, что деформационная анизотропия уширения рефлексов в образцах может быть вызвана наличием дефектов и дислокаций.

Согласно оценке, средний размер зерен $(D)$ увеличивается от $66 \pm 10$ нм для пленки $\mathrm{PbS}$ до $220 \pm 20 \mathrm{Hм}$ для слоя $\mathrm{PbS}(\mathrm{I})$ и $240 \pm 30$ нм для $\mathrm{PbS}(\mathrm{I}, \mathrm{Ba})$ и $\mathrm{PbS}(\mathrm{I}, \mathrm{Sr})$ при минимальной концентрации легирующей соли $\left(\mathrm{SrCl}_{2}\right.$ или $\left.\mathrm{BaCl}_{2}\right)$ в реакторе. При максимальной концентрации допантов в реакторе пленку $\mathrm{PbS}(\mathrm{I}, \mathrm{Sr})$ формируют более крупные зерна со средними размерами зерна $380 \pm 50$ нм, а слой $\mathrm{PbS}(\mathrm{I}, \mathrm{Ba})$ - зерна с $D=285 \pm 50$ нм. Результаты оценки среднего размера частиц в пленках $\mathrm{PbS}(\mathrm{I}), \mathrm{PbS}(\mathrm{I}, \mathrm{Ba})$ и $\mathrm{PbS}(\mathrm{I}, \mathrm{Sr})$ методами рентгеновской дифракции и электронной микроскопии достаточно хорошо согласуются между собой. 


\section{3. Оптические свойства}

Прежде чем анализировать влияние введения легирующих добавок в реакционную смесь на оптические свойства синтезированных пленок сульфид свинца, необходимо сравнить свойства тонкопленочных слоев, полученных без добавления иодида аммония $(\mathrm{PbS})$ и в его присутствии $-\mathrm{PbS}(\mathrm{I})$. На рис. 4, $a$ показаны спектры поглощения $\alpha(E)$ обсуждаемых пленок, измеренные при комнатной температуре. Видно, что введение добавки иода приводит к образованию в спектре поглощения примесной полосы на краю фундаментального поглощения, а также к незначительному уменьшению поглощения в области $0.25-0.3$ эВ. Вычитание спектра поглощения пленки $\mathrm{PbS}$ из спектра, соответствующего пленке $\mathrm{PbS}(\mathrm{I})$, свидетельствует о том, что в результате добавки иодида аммония в реакционную ванну в процессе осаждения сульфида свинца происходит исчезновение примесной полосы поглощения $(A)$ с максимумом при 0.28 эВ (на рис. $4, c$ соответствует минимуму на кривой $\alpha_{2}-\alpha_{1}$ ). Как отмечается в [26], в этой спектральной области находится полоса поглощения, связанная с вакансиями серы, образующими квазилокальный уровень в глубине валентной зоны. Это согласуется с данными EDXанализа для исследуемых нами тонкопленочных слоев: переход от пленки $\mathrm{PbS}$ к $\mathrm{PbS}(\mathrm{I})$ сопровождается сменой дефицита в подрешетке серы на дефицит в подрешетке свинца (см. таблицу). Этот же разностный спектр $\alpha_{2}-\alpha_{1}$ указывает на сложный характер дополнительной полосы поглощения, которая появляется в области $0.4-0.5$ эВ. Видно, что дополнительная полоса состоит как минимум из двух подполос с максимумами при $E=0.43$ эВ и 0.52 эВ (на рис. $4, c$ обозначены как $B$ и $C)$.

Введение хлорида бария или стронция в количестве 0.05 ммоль/л в реакционную ванну не влияет на спектры в области фундаментального поглощения, кривые $\alpha(E)$ практически совпадают (рис. 4, $a$ ). Незначительное различие наблюдается лишь в области высокоэнергетической примесной полосы, которая, как видно из сравнения спектров пленок $\mathrm{PbS}$ и $\mathrm{PbS}(\mathrm{I})$, связана с ионами иода. Интенсивность этой полосы увеличивается на $\sim 5 \%$ при переходе от пленки $\mathrm{PbS}(\mathrm{I})$ к пленке $\mathrm{PbS}(\mathrm{I}, \mathrm{Sr})$, а затем $\mathrm{PbS}(\mathrm{I}, \mathrm{Ba})$. В низкоэнергетической части спектра также видны небольшие изменения при введении легирующей добавки стронция или бария в реакционную смесь: рост поглощения с уменьшением энергии начинается при больших энергиях, а изменения интенсивности такие же, как в области высокоэнергетической полосы. Причем наибольшее изменение наблюдается для пленки, синтезированной в присутствии хлорида бария. Кривые $\alpha_{3}-\alpha_{2}$ и $\alpha_{4}-\alpha_{2}$, соответствующие разности спектров пленок $\operatorname{PbS}(\mathrm{I}, \mathrm{Sr}), \operatorname{PbS}(\mathrm{I}, \mathrm{Ba})$ и $\mathrm{PbS}(\mathrm{I})$, указывают на то, что введение хлоридов стронция или бария в реакционную ванну вновь приводит к появлению примесной полосы при 0.28 эВ (рис. $4, c)$.
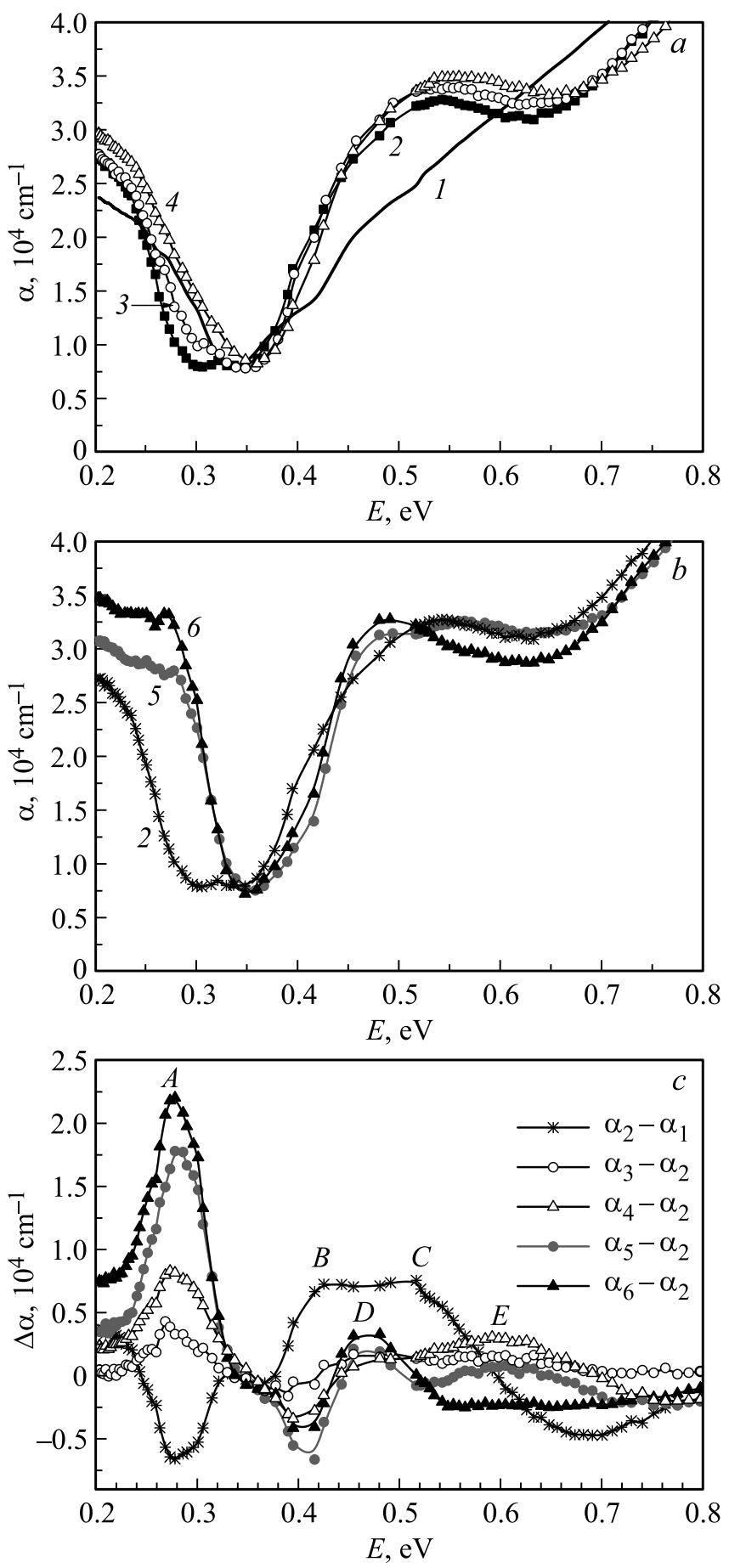

Pис. 4. Спектры поглощения пленок $\mathrm{PbS}(1), \operatorname{PbS}(\mathrm{I})$ (2), $\mathrm{PbS}(\mathrm{I}, \mathrm{Sr})(3,5)$ и $\mathrm{PbS}(\mathrm{I}, \mathrm{Ba})(4,6)$, синтезированных из реакционных смесей с добавлением $\mathrm{SrCl}_{2}$ или $\mathrm{BaCl}_{2}$ в количестве 0.05 ммоль/л $(a)$ и 5 ммоль/л $(b)$, и разность $(c)$ спектров поглощения (номера пленок указаны на рисунке). Спектры измерены при комнатной температуре.

Рассмотрим влияние введения бо́льшего количества соли бария и стронция (5.0 ммоль/л). В области фундаментального поглощения $(E>0.7$ э) спектры пленок $\mathrm{PbS}(\mathrm{I})$ и $\mathrm{PbS}(\mathrm{Sr}), \operatorname{PbS}(\mathrm{Ba})$ вновь совпадают, а при 

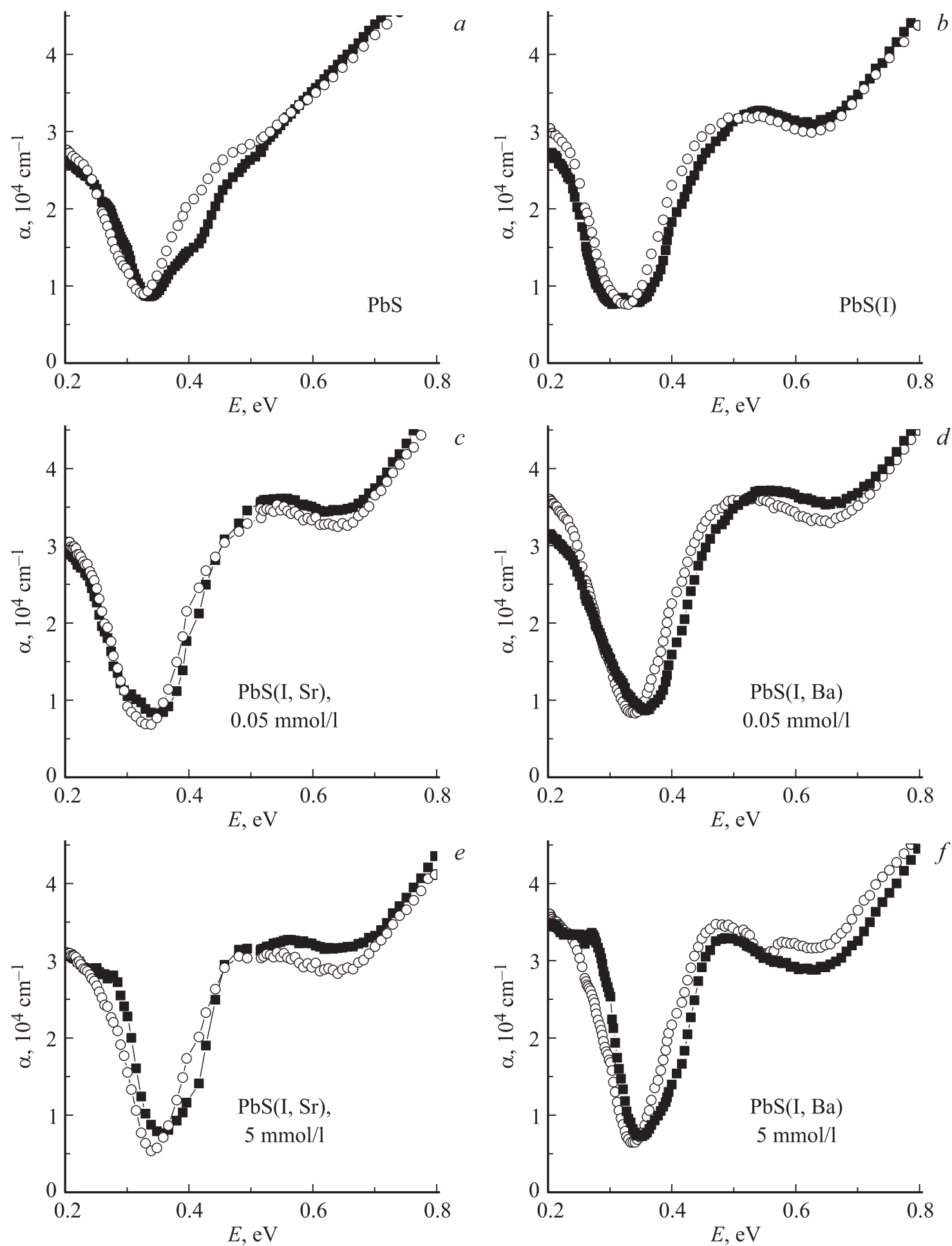

Рис. 5. Спектры поглощения пленок $\mathrm{PbS}(a), \mathrm{PbS}(\mathrm{I})(b), \mathrm{PbS}(\mathrm{I}, \mathrm{Sr})(c, d), \mathrm{PbS}(\mathrm{I}, \mathrm{Ba})(e, f)$, измеренные при комнатной температуре (сплошные квадраты) и при $T=90 \mathrm{~K}$ (открытые кружки).

меньших энергиях можно выделить следующие основные изменения в спектрах, связанные с легированием. Во-первых, интенсивность примесной полосы поглощения $(A)$ при 0.28 эВ увеличивается. При этом полоса становится отчетливо видна не только на разностных спектрах $\alpha_{5}-\alpha_{2}$ и $\alpha_{6}-\alpha_{2}$ (рис. $4, c$ ), но и в спектрах поглощения (рис. $4, b$ ). Наибольшую интенсивность имеет полоса поглощения в спектре пленки, осажденной из реакционной ванны, содержащей $\mathrm{BaCl}_{2}$.

Во-вторых, сложная полоса поглощения в области 0.4-0.5 эВ меняет свою структуру. Низкоэнергетическая подполоса $(B)$ с максимумом при 0.43 эВ умень- 
шается (в соответствующих разностных спектрах на рис. 4, с появляется минимум). Наибольшее изменение полосы $(B)$ наблюдается для пленки $\mathrm{PbS}(\mathrm{I}, \mathrm{Sr})$. Одновременно с этим проявляется полоса при 0.47 эВ $(D)$, которая приходится на область между полосами $(B)$ и $(C)$, наблюдающимися в спектре пленки $\mathrm{PbS}(\mathrm{I})$. Как видно из рис. $4, b$, соотношение интенсивностей этой дополнительной полосы $(D)$ в $\mathrm{PbS}(\mathrm{I}, \mathrm{Sr}), \mathrm{PbS}(\mathrm{I}, \mathrm{Ba})$ такое же, как при 0.28 эВ.

Кроме того, в пленке, синтезированной с добавлением 5.0 ммоль/л хлорида бария, происходит уменьшение поглощения в области 0.6 эВ (особенность $(E)$ на pис. $4, b, c)$, а в пленке, синтезированной в присутствии той же концентрации хлорида стронция, в этой области спектра изменений не происходит.

Наблюдаемая эволюция спектра поглощения сульфида свинца при введении в реакционную смесь хлоридов стронция или бария в количестве 5.0 ммоль/л может быть связана с изменением соотношения дефектов в пленке. Такое предположение следует из того, что в пленке $\mathrm{PbS}(\mathrm{I}, \mathrm{Ba})$ изменения в спектре наиболее сильные, а металл-допант при этом в пленке не обнаружен. В качестве дефектов, создающих дополнительные примесные полосы поглощения, могут быть вакансии в обеих подрешетках сульфида свинца, ионы свинца, находящиеся в междоузлии, либо ионы иода.

Спектры поглощения для всех пленок были измерены не только при комнатной температуре, но и при $T=90 \mathrm{~K}$. Охлаждение приводило к следующим изменениям в спектрах (рис. 5). В пленке $\mathrm{PbS}$ при понижении температуры происходит красный сдвиг края поглощения, что типично для сульфида свинца [27]. В пленке $\mathrm{PbS}(\mathrm{I})$ в области (сложной) полосы с максимумом при 0.5-0.55эВ происходит красный сдвиг края полосы. Такое изменение может быть связано как со сдвигом края поглощения, на фоне которого существует данная полоса, так и с увеличением интенсивности подполосы при 0.4 э, существование которой следует из анализа предыдущего рисунка. В низкоэнергетической области спектра $(E<0.3$ эВ) поглощение увеличивается при охлаждении. Это может быть объяснено увеличением интенсивности полосы при 0.28 эВ.

Для пленок сульфида свинца, полученных из реакционных смесей с максимальной концентрацией хлоридов стронция или бария, в области полосы с максимумом при 0.5 эВ изменение подобно тем, что наблюдаются в слабо легированных слоях и в исходной пленке. В области низких энергий понижение температуры приводит К заметному уменьшению интенсивности примесной полосы для пленок $\mathrm{PbS}(\mathrm{I}, \mathrm{Sr})$ и $\mathrm{PbS}(\mathrm{I}, \mathrm{Ba})$ на 22 и 27\% соответственно. В результате вид кривой поглощения при $T=90 \mathrm{~K}$ становится близок к спектру $\alpha(E)$, соответствующему слабо легированной пленке. В то же время в области подполосы при 0.43 эВ наблюдается увеличение поглощения при понижении температуры.

Вычитание спектров поглощения, измеренных при различных температурах, свидетельствует о перераспре-
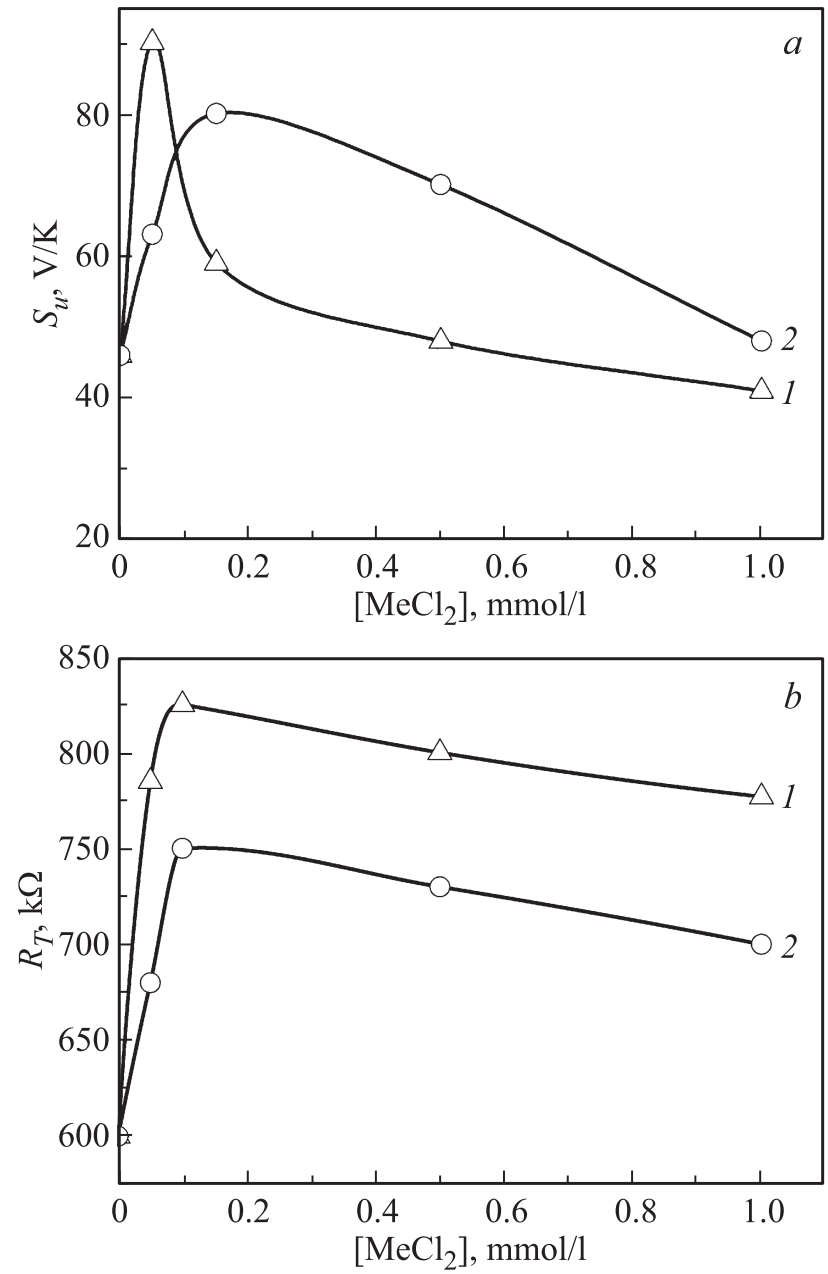

Рис. 6. Зависимости вольт-ваттной чувствительности $S_{U}(a)$ и темнового сопротивления $R_{T}(b)$ элементов $5 \times 5$ мм на основе пленок $\mathrm{PbS}$ от концентрации в реакционной смеси хлоридов стронция (1) и бария (2).

делении интенсивности из области полосы $(A)$ с максимумом при 0.28 эВ в область полосы $(B)$ с максимумом при 0.43 эВ, указывая на общую природу этих полос. Их общая природа также подтверждается одинаковой эволюцией в зависимости от содержания соли-допанта в реакционной смеси, как видно из рис. $4, c$.

\section{4. Фоточувствительные свойства}

Следует отметить, что синтезированные в работе легированные пленки сульфида свинца $\mathrm{PbS}(\mathrm{I}, \mathrm{Sr})$ и $\mathrm{PbS}(\mathrm{I}, \mathrm{Ba})$ характеризуются фоточувствительностью к излучению в видимом и ближнем ИК-диапазоне спектра без проведения дополнительной операции термосенсибилизации. На рис. 6 приведены зависимости вольтваттной чувствительности $S_{U}$ и „темнового“ сопротивления $R_{T}$ чувствительных элементов $5 \times 5$ мм, изготовленных на их основе, от концентрации хлоридов металлов в реакционной ванне: стронция (1) и бария (2). 
Видно, что зависимости как омического сопротивления, так и воль-ваттной чувствительности от концентрации соли легирующего металла $(\mathrm{Sr}, \mathrm{Ba})$ в реакционной ванне имеют экстремальный характер. Это связано, в первую очередь, с влиянием вводимых добавок на процесс роста кристаллитов, осаждаемых слоев, изменение их размеров и формы. Максимальному омическому сопротивлению соответствует концентрация введенной добавки соли как стронция, так и бария в реакторе, равная 0.1 ммоль/л. При дальнейшем увеличении содержания соли допанта наблюдается монотонное снижение омического сопротивления до 770 и 700 кОм при 1 ммоль/л, а при 5 ммоль/л составляет 735 и 690 кОм соответственно для пленок $\mathrm{PbS}(\mathrm{I}, \mathrm{Sr}), \mathrm{PbS}(\mathrm{I}, \mathrm{Ba})$.

Что касается вольт-ваттной чувствительности пленок $\mathrm{PbS}(\mathrm{I}, \mathrm{Sr})$ и $\mathrm{PbS}(\mathrm{I}, \mathrm{Ba})$, то ее максимальные значения достигаются соответственно при 0.05 и 0.1 ммоль/л, причем при более низком уровне фотоответа для пленок, осажденных с добавкой бариевой соли. Выявленная особенность является следствием более слабого влияния добавки хлорида бария на процесс осаждения и свойства пленок $\mathrm{PbS}$. Дальнейшее повышение концентрации легирующей добавки до 5 ммоль/л в реакторе приводит к незначительному снижению вольт-ваттной чувствительности (до 34-28 В/Вт).

Отметим, что с учетом данных [17] приведенные величины вольт-ваттной чувствительности пленок сульфида свинца, легированных стронцием $\mathrm{PbS}(\mathrm{I}, \mathrm{Sr})$ и барием $\mathrm{PbS}(\mathrm{I}, \mathrm{Ba})$, превышают аналогичный параметр для чувствительных элементов на основе пленки $\mathrm{PbS}(\mathrm{I}, \mathrm{Ca})$ в 2.1 и 1.9 раз соответственно, причем при более высокой концентрации введенного допанта (5 ммоль/л), чем при легировании стронцием и барием.

\section{4. Заключение}

Гидрохимическим осаждением в присутствии $\mathrm{NH}_{4} \mathrm{I}$, добавок солей стронция и бария получены пленки $\mathrm{PbS}$, $\mathrm{PbS}(\mathrm{I}), \operatorname{PbS}(\mathrm{I}, \mathrm{Sr})$ и $\mathrm{PbS}(\mathrm{I}, \mathrm{Ba})$ толщиной 200-400 нм кубической структуры $B 1$ с пр. гр. $F m \overline{3} m$. EDX-анализом показано, что в составе синтезированных пленок существует незначительный избыток свинца при содержании иода от 0.4 до 1.4 ат\%. Содержание стронция составляет от 0.4 до 0.7 ат\%, а содержание бария находится ниже ошибки определения. Легирование пленок иодом, стронцием и барием сопровождается изменением текстурирования пленки: для пленки $\mathrm{PbS}$ имеется часть кристаллитов, ориентированных плоскостью (111) перпендикулярно подложке, а в пленках $\mathrm{PbS}(\mathrm{I}), \mathrm{PbS}(\mathrm{I}, \mathrm{Sr})$ и $\mathrm{PbS}(\mathrm{I}, \mathrm{Ba})$ кристаллиты ориентированы плоскостью (200). Доля ориентированных кристаллитов больше в пленках, осажденных из растворов с максимальной концентрацией соли стронция или бария. Включение иода приводит к увеличению периода решетки $\mathrm{PbS}$ от 0.59326(2) до $0.59343(2)$ нм в результате замещения ионов серы $\mathrm{S}^{2-}$ иодид-ионами либо их внедрения в междоузлия. В свою очередь изменения периода решетки при осаждении в присутствии солей $\mathrm{Sr}$ и Ва связаны как с различным содержанием в ней иода и замещением свинца, так и с возникновением структурных дефектов. Во всех исследованных пленках присутствует выраженная анизотропия микронапряжений. Установлена тенденция снижения от 1.13 ат\% до следовых количеств содержания в пленках щелочноземельных металлов в ряду от кальция к барию, что коррелирует с ростом их ионных радиусов.

Осаждение пленок $\mathrm{PbS}$ в присутствии солей стронция и бария не приводит к изменению края поглощения. На начальном этапе легирования лишь изменяется спектр поглощения в низкоэнергетической части в области полосы примесного поглощения при 0.28 эВ. При увеличении легирующей добавки в растворе в спектрах кроме полосы при 0.28 эВ дополнительно меняется интенсивность сложной примесной полосы в области 0.4-0.5 эВ. Наблюдаемые изменения спектров как при минимальном, так и при максимальном легировании значительнее при использовании в качестве легирующей добавки хлорида бария. Охлаждение слоев приводит к перераспределению спектрального веса из области полосы при 0.28 эВ в область полосы при 0.43 эВ, указывая на их общую природу.

Зависимости омического сопротивления и вольтваттной чувствительности пленок от концентрации в растворе солей $\mathrm{Sr}$ и Ва имеют экстремальный характер с максимумами вольт-ваттной чувствительности при 0.05 и 0.1 ммоль/л соответственно. Полученные значения превышают в 2.1 и 1.9 раза аналогичный параметр для слоев $\mathrm{PbS}(\mathrm{I}, \mathrm{Ca})$.

\section{Финансирование работы}

Работа выполнена при финансовой поддержке программы 211 Правительства Российской Федерации № 02.А03.21.0006, с использованием средств планового задания А-19-1190318.90025-9 и государственного задания МИНОБРНАУКИ России (тема „Поток“ № AAAA-A18-118020190112-8, тема „Спин“ № АAАAA18-118020290104-2), а также при частичной поддержке РФФИ (грант № 18-29-11051 мк).

\section{Конфликт интересов}

Авторы заявляют, что у них нет конфликта интересов.

\section{Список литературы}

[1] Л.Н. Курбатов. Вопросы оборонной техники, 11, 3 (1995).

[2] A.B. Rohom, P.U. Londhe, P.R. Jadhav, G.R. Bhand, N.B. Chaure. J. Mater. Sci.: Mater. Electron., 28, 17107 (2017). https://doi.org/10.1007/s10854-017-7637-4

[3] В.Ф. Марков, Л.Н. Маскаева. Журн. аналит. химии, 56, 846 (2001).

[4] И.В. Зарубин, В.Ф. Марков, Л.Н. Маскаева, Н.В. Зарубина, М.В. Кузнецов. Журн. аналит. химии, 72, 266 (2017). 
[5] В.Ф. Марков, Л.Н. Маскаева А.В. Шнайдер, Р.Х. Сарыева. Техносферная безопасность, 1, 32 (2015).

[6] A.S. Obaid, Z. Hassan, M.A. Mahdi, M. Bououdina. Sol. Energy, 89, 143 (2013).

[7] P. Wang, L. Cao, Y. Wu, J. Di. Microchim. Acta, 185, 356 (2018).

[8] В.Ф. Марков, Л.Н. Маскаева, Г.А. Китаев. ЖПХ, 73, 1256 (2000).

[9] Т.А. Алексеева, В.Ф. Марков, Л.Н. Маскаева, Н.А. Третьякова, В.И. Воронин. Бутлеровские сообщения, 17, 3 (2009).

[10] В.И. Кайданов, Ю.И. Равич. УФН, 145, 51 (1985).

[11] C. Rajashree, A.R. Balu, V.S. Nagarethinam. J. Mater. Sci.: Mater. Electron., 27, 5078 (2016).

[12] A. Gassoumi, S. Alleg, N. Kamoun-Turki. J. Molecul. Struct., 1116, 67 (2016).

[13] Y. Yücel, B. Beleli. Mater. Res. Express, 5, 056408 (2018).

[14] M.M. Tavakolia. Procedia Eng., 139, 117 (2016).

[15] E. Yücel, Y. Yücel. Optik, 142, 82 (2017).

[16] E. Yücel, Y. Yücel. Ceram. Intern., 43, 407 (2017).

[17] Л.Н. Маскаева, Е.В. Мостовщикова, В.Ф. Марков, В.И. Воронин. ФТП, 53, 174 (2019).

[18] Gülen. Acta Phys. Polon., 126, 763 (2014).

[19] Л.Н. Маскаева, Е.Э. Лекомцева, В.Ф. Марков, А.Д. Кутявина. Бутлеровские сообщения, 58, 90 (2019).

[20] D.L. Bush, J.E. Post. Rev. Mineralogy, 20, 369 (1990).

[21] J. Rodriges-Carvajal. Physica B.: Condens. Matter, 192, 55 (1993).

[22] Р.Ф. Зайкина, Г.А. Борзова, Н.Р. Мажренова. Вестн. КазГУ, Сер. физ., 2, 108 (1995).

[23] В.С. Урусове. Теоретическая кристаллохимия (М., МГУ, 1987).

[24] З.И. Смирнова, В.М. Баканов, Л.Н. Маскаева, В.Ф. Марков, В.И. Воронин. ФТТ, 56 (12), 2468 (2014).

[25] T. Ungar, I. Dragomir, A. Revesz, A. Borbely. J. Appl. Cryst., 32, 992 (1999).

[26] А.Н. Вейс. Науч.-техн. ведомости СПбГПУ. Физ.-мат. науки, 213, 9 (2015).

[27] W.W. Scanlon. Solid State Phys., 9, 83 (1959).

\section{Structure, optical and photoelectric properties of lead sulfide films doped with strontium and barium}

\author{
L.N. Maskaeva ${ }^{1,2}$, E.V. Mostovshchikova ${ }^{3}$, \\ V.I. Voronin ${ }^{3}$, E.E. Lekomtseva ${ }^{1}$, \\ P.S. Bogatova ${ }^{1}$, V.F. Markov ${ }^{1,2}$ \\ ${ }^{1}$ Ural Federal University named after \\ the first President of Russia B.N. Yeltsin, \\ 620002 Yekaterinburg, Russia \\ ${ }^{2}$ Ural State Fire Service Institute \\ of Emergency Ministry of Russia, \\ 620022 Yekaterinburg, Russia \\ ${ }^{3}$ Miheev Institute of Metal Physics of Ural Branch \\ of Russian Academy of Sciences, \\ 620108 Yekaterinburg, Russia
}

\begin{abstract}
The morphological evolution of composition, structural characteristics (lattice constant, microdeformations, texturing), optical and photoelectric properties of $\mathrm{PbS}$ films obtained by chemical bath deposition in the presence of ammonium iodide and strontium/barium chlorides at a concentration range up to $5 \mathrm{mmol} / 1$ was studied. According to elemental EDX analysis, the strontium content in PbS films was $0.4-0.7$ at $\%$, whereas barium concentration was beyond the determination error interval. The size of the particles forming the $\mathrm{PbS}$ films ranged from $\sim 200$ to $\sim 400 \mathrm{~nm}$ with monomodal particle size distribution. The introduction of $\mathrm{NH}_{4} \mathrm{I}$ and $\mathrm{SrCl}_{2} / \mathrm{BaCl}_{2}$ into the bath retained the cubic $B 1$ structure of $\mathrm{PbS}$ films, but led to a nonmonotonic change in the lattice parameter, which was associated with the defects, namely, vacancies or interstitial ions. The introduction of strontium and barium salts had no effect on the PbS band gap, but led to a change in the intensities of the impurity absorption bands in the depth and near the bottom of the conduction band. The dependence of the volt-watt sensitivity of the $\mathrm{PbS}$ films upon the concentration of strontium/barium in the solution was extreme with maxima at 0.05 and $0.1 \mathrm{mmol} / 1$, respectively.
\end{abstract}

